\title{
Pengaturan Rules of Origin di Indonesia dan Masalah-Masalah Hukum Yang Ditimbulkannya
}

\author{
Emmy Latifah \\ Fakultas Hukum Universitas Sebelas Maret \\ Email: emmy.latifah@yahoo.com
}

\begin{abstract}
Rules of origin is used to determine the origin of products in order to receive preferential tariff facility. It means that only the products which are from certain countries or certain region that have been bound the preferential trade agreements which entitled on the preferential tariff. Moreover, rules of origin also plays the role to prevent trade deflection. In this context, it becomes the mechanism to preclude import products that do not originate from a particular countries or region through the state which applies the lowest external tariff. Therefore, regulating rules of origin in each country bound the preferential trade agreement is needed. This research examined how Indonesia regulated rules of origin in its national legal order and the legal problems arose from its regulation. Indonesian rules of origin defined limited to technical rule. As a result, Indonesia has the potential to be harmed in international trade traffic. In addition, institutional problem is also a matter of concern. Because Indonesia does not have a special agency dealing with rules of origin, thus it creates difficulty for many parties, not just the perpetrators of international trade, but also the government.
\end{abstract}

Keywords: rules of origin, regulation, legal problems, Indonesia

\begin{abstract}
Abstrak
Rules of origin adalah mekanisme yang digunakan untuk menentukan asal produk dalam rangka mendapatkan fasilitas tarif preferensial. Hanya produk-produk yang berasal dari negara tertentu yang telah terikat pada satu perjanjian preferensial saja yang dapat menikmati tarif preferensial. Selain itu, rules of origin juga berfungsi untuk mencegah defleksi perdagangan. Dalam konteks ini, rules of origin menjadi mekanisme pencegahan masuknya produk-produk yang bukan berasal dari kawasan tertentu melalui negara yang menerapkan tarif eksternal paling rendah. Oleh sebab itu, pengaturan rules of origin di setiap negara yang terlibat dalam perjanjian perdagangan preferensial sangat diperlukan. Penelitian ini bertujuan untuk mengetahui pengaturan rules of origin di Indonesia dan masalah-masalah hukum yang ditimbulkan dari pengaturan tersebut. Hasil penelitian menunjukkan bahwa Indonesia belum memiliki aturan rules of origin yang bersifat komprehensif. Aturan mengenai rules of origin di Indonesia masih dimaknai sebatas aturan teknis saja. Akibatnya, Indonesia berpotensi untuk dirugikan dalam lalu lintas perdagangan internasional. Selain itu, masalah kelembagaan juga menjadi hal yang perlu diperhatikan. Indonesia belum memiliki lembaga yang
\end{abstract}


khusus menangani rules of origin, sehingga hal ini menyulitkan banyak pihak, tidak saja pihak pelaku perdagangan internasional, tapi juga pihak pemerintah.

\section{Kata kunci: rules of origin, pengaturan, masalah hukum, Indonesia.}

\section{A. Pendahuluan}

Seiring meningkatnya kerjasama yang didasarkan pada perjanjian perdagangan preferensial (preferential trade agreements), meningkat pula peran rules of origin. Rules of origin (atau yang sering disingkat ROO) adalah aturan untuk menentukan asal suatu produk melalui kriteria tertentu (Bashar H. Malkawi, 2011: 29). Sementara preferential trade agreement (PTA) adalah perjanjian perdagangan dalam suatu kawasan perdagangan yang memberikan keistimewaan untuk produk-produk tertentu dari negara anggota dengan memberikan pengurangan tarif, tetapi tidak kepada negara yang bukan anggota (Jagdish Bhagwati, 2008: xi). Dalam konteks ini, rules of origin berfungsi untuk mencegah defleksi perdagangan, yaitu mencegah masuknya barang-barang yang berasal dari negara bukan anggota dan menikmati manfaat perdagangan (seperti penghapusan tarif atau mendapatkan tarif preferensial dari skema Generalized System of Preference/GSP) melalui negara-negara yang menerapkan tarif eksternal paling rendah (Kala Khrishna, 2005: 3).

Seiring semakin meningkatnya kerjasama regional, meningkat pula kompleksitas hubungan perdagangan antar negara, khususnya berkaitan dengan rantai produksi yang dilakukan perusahaan multinasional yang bergerak di bidang pengadaan bahan baku, suku cadang, komponen dan jaringan produksi (Jacques H.J. Bourgeois, 1994: 4-5). Jika sebuah produk sepenuhnya diproduksi di satu negara saja, maka menentukan asal produk bukan hal yang sulit (John J. Barcelo III, 2006: 4). Namun, apabila suatu produk dihasilkan melalui pengolahan dari berbagai gabungan input (input di sini bisa berupa bahan baku, suku cadang dan bahan intermediet) yang berasal dari sumber daya dari negara yang berbeda-beda, maka menentukan asal barang akan menjadi hal yang rumit. Dalam hal ini, rules of origin diperlukan untuk menentukan negara asal produk ketika proses produksi 
maupun inputnya terjadi dan berasal dari lebih dari satu negara guna mendapatkan fasilitas preferensial (Rajan Sudesh Ratna, 1993: 691-712).

Pengaturan rules of origin yang berbeda-beda pada tiap negara dapat mengganggu aliran perdagangan internasional. Permasalahan akan muncul ketika terdapat beberapa produk yang sama yang berasal dari negara yang berbeda dikenai aturan yang berbeda di tiap negara dalam satu kawasan. Selain itu, perbedaan aturan rules of origin di suatu negara dapat memaksa produsen global untuk menambah proses manufaktur tertentu dalam mata rantai produksinya di negara tersebut sehingga mengakibatkan biaya yang tinggi (Ram Upendra Das and Rajan Sudesh Ratna, 2011:10-11).

Penelitian ini mengkaji pengaturan rules of origin dalam dalam tata hukum Indonesia dan masalah-masalah hukum yang timbul dari pengaturan tersebut.

\section{B. Metode Penelitian}

Penelitian ini adalah penelitian hukum normatif, yang bersifat exploratifanalitis. Data yang digunakan adalah data sekunder, berupa bahan hukum primer dan bahan hukum sekunder (Soerjono Soekanto dan Sri Mamudji, 2007: 13-14). Bahan hukum primer meliputi konvensi dan peraturan perundang-undangan yang berkaitan dengan rules of origin, baik di tingkat internasional, regional, maupun nasional; sedangkan bahan hukum sekunder berupa jurnal-jurnal yang membahas mengenai rules of origin. Data sekunder ini diperoleh melalui studi pustaka. Teknik analisis data menggunakan penafsiran hukum gramatikal. Validasi data dilakukan melalui kritik sumber.

\section{Hasil Penelitian dan Pembahasan}

1. Rules of Origin dalam Sistem Hukum Perdagangan Internasional
a. Perkembangan Pengaturan Rules of Origin dalam Sistem Hukum Perdagangan Internasional

Upaya untuk menyusun konsep rules of origin dapat ditelusuri sejak tahun 1923 di mana The International Convention relating to the Simplification of 
Customs Formalities - walaupun belum memberi batasan yang jelas mengenai rules of origin - telah menguraikan berbagai langkah untuk menyederhanakan prosedur dan formalitas yang berkaitan dengan verifikasi asal barang (UNCTAD, 2011: 8). Konvensi ini selain mengatur isu-isu tentang penerbitan dan penerimaan sertifikat asal barang, juga memberikan kesempatan kepada swasta untuk mengeluarkan sertifikat asal barang. Selain itu, Konvensi juga mengatur mengenai penerimaan sertifikat keaslian barang yang dikeluarkan oleh pihak ketiga jika barang tidak diimpor dari negara asalnya. Ketentuan dalam Konvensi ini menunjukkan bahwa menentukan asal barang dapat dilakukan secara bebas, artinya dapat dilakukan dengan metode apapun. Hal ini disebabkan karena pada kenyataannya negara-negara hampir tidak menghadapi hambatan hukum atau intervensi selama menentukan asal barang (Ram Upendra Das dan Rajan Sudesh Ratna, 2011: 12).

Pada periode rezim GATT 1947, tidak ada aturan multilateral yang mengatur ketentuan asal barang kecuali Pasal IX yang berkaitan dengan persyaratan penandaan (marking requirements). Sementara, pedoman untuk menerbitkan sertifikat asal barang yang terdapat di dalam Notes and Supplementary Provisions pada Ad Article VIII menyatakan: “..."It will be consistent with paragraph 1 if, on the importation of products from the territory of a contracting party, the production of certificates of origin should only be required to the extent that is strictly indispensable." Hal ini membuktikan bahwa menentukan asal barang dianggap tidak begitu penting karena hanya termuat di dalam Notes and Supplementary Provisions dan ini hanya diperlukan pada situasi yang benar-benar diperlukan (strictly indispensable) (Ram Upendra Das and Rajan Sudesh Ratna, 2011: 11).

Kekosongan aturan asal barang teratasi dengan disetujuinya The International Convention on the Simplification and Harmonization of Customs Procedures 1973, atau yang lebih sering di sebut Konvensi Kyoto 1973. Annex DI Konvensi, mendefinisikan rules of origin sebagai: “...the specific provisions, developed from principles established by national legislation or international agreements applied by a country to determine the origin of goods." 
Definisi ini masih mengandung ketidakjelasan karena aturan menentukan asal barang tergantung pada peraturan perundang-undangan nasional uatu negara atau konvensi internasional. Hal ini akan menimbulkan kesulitan jika metode yang dianut oleh satu negara berbeda dengan negara lain.

Pada periode Putaran Uruguay, negara-negara sepakat untuk menegosiasikan kerangka kerja untuk mengharmonisasikan Non-Preferential Rules of Origin (NPROO) dan Preferential Rules of Origin (PROO) karena adanya ketidakseragaman dalam menentukan asal barang. Agreement on Rules of Origin (AROO) adalah konvensi yang dihasilkan dari negosiasi tersebut dan menjadi bagian terintegrasi dalam Agreement Establishing of World Trade Organization (Annex 1A). AROO membedakan pengertian NPROO dan PROO sebagai berikut.

“...Non-Preferential Rules of Origin shall be defined as those laws, regulations and administrative determinations of general application applied by any Member to determine the country of origin of goods provide such rules of origin are not related to contractual or autonomous trade regimes leading to the granting of tariff preference going beyond the application of paragraph 1 of Article 1 of GATT 1994." (Pasal 1 Paragraf 1 AROO).

"Preferential Rules of Origin shall be defined as those laws, regulations and administrative determinations of general application applied by any Member to determine whether goods qualify for preferential treatment under contractual or autonomous trade regimes leading to the granting of tariff preferences going beyond the application of paragraph a of Article 1 of GATT 1994"'(Annex II Paragraf 2 AROO).

Non-preferential ROO (NPROO) didefinisikan sebagai aturan atau pedoman administratif yang digunakan untuk mengetahui negara asal barang, namun aturan ini tidak berhubungan dengan perjanjian perdagangan tertentu yang akan memberikan tarif preferensial yang melampaui penerapan dalam Paragraf 1 Pasal 1 GATT 1947. Tujuan dari NPROO ini adalah untuk pelaksanaan antidumping dan countervailing measures, tindakan pengamanan, persyaratan penanda asal, pembatasan kuantitatif diskriminatif atau kuota tarif, serta untuk tujuan pengadaan barang pemerintah (Thinam Jakob and Gernot Fiebiger, 2003: 139). 
Sementara Agreement on Rules of Origin mendefinisikan preferential rules of origin (PROO) sebagai suatu aturan yang digunakan untuk menentukan asal barang dengan tujuan untuk mendapatkan fasilitas tarif preferensial dari negara pengimpor. Dalam hal ini, rules of origin yang berlaku dalam konteks perjanjian perdagangan preferensial digunakan untuk menentukan apakan suatu barang memenuhi kriteria untuk mendapatkan perlakuan preferensial (Jong Bum and Joongi Kim, 2009:153).

Tujuan utama dari Agreement ini adalah: menyusun aturan nonpreferential rules of origin yang harmonis yang disepakai secara multilateral untuk semua produk ke dalam nomenklatur Harmonized System, di mana kemudian aturan rules of origin apat digunakan untuk semua tujuan nonpreferential rules of origin (Pasal 9); menetapkan prinsip-prinsip yang akan berlaku dalam penerapan non-preferential rules of origin yang harmonis setelah aturan tersebut diadopsi dan mulai berlaku (Pasal 3); menetapkan prinsip-prinsip yang akan diberlakukan dalam penerapan non-preferential rules of origin pada masa transisi hingga proses harmonisasi tercapai dan berlaku (Pasal 2).

\section{b. Prinsip-prinsip Rules of Origin}

Terdapat tujuh prinsip rules of origin yang terdapat pada Pasal 9 Agreement on Rules of Origin yaitu:

1) Prinsip non-discrimination/equal bahwa ROO selain untuk tujuan preferensial juga harus diberlakukan sama untuk tujuan non-preferensial.

2) Prinsip objective, understandable and predictability, bahwa ROO harus bersifat objektif, dapat dipahami dan dapat diprediksi.

3) Prinsip transparency, bahwa ROO tidak boleh digunakan sebagai instrumen, baik langsung maupun tidak langsung, untuk mencapai tujuan kebijakan perdagangan.

4) Prinsip consistent, uniform, impartial and reasonable manner; bahwa secara administratif, ROO harus bersifat konsisten, seragam, tidak memihak dan wajar (masuk akal). 
5) Prinsip neutrality, bahwa ROO tidak boleh mengandung pengaruh yang membatasi, menyimpang dan mengganggu perdagangan internasional.

6) Prinsip coherent, bahwa aturan ROO harus jelas dan mudah dimengerti.

7) Prinsip positive standard, bahwa ROO harus mengandung standar yang bersifat positif. Standar negatif digunakan untuk mengklarifikasi standar positif.

\section{c. Mekanisme Menentukan Asal Barang}

Berdasarkan Convention on Rules of Origin, ada dua cara menentukan kriteria asal barang, yaitu: (a) wholly obtained criterion; (b) not wholly obtained criterion/substantial transformation criterion. Kriteria untuk klasifikasi barang yang masuk "wholly obtained or produced" ditafsirkan secara ketat. Bahkan isi minimal dari input impor, bagian atau komponen, atau bahan yang tidak dapat ditentukan asalnya dapat membuat suatu barang jadi kehilangan klasifikasi sebagai "wholly obtained or produced" (Stefano Inama, 2009: 179). Oleh sebab itu, setiap PTA memiliki daftar barang yang masuk dalam klasifikasi ini. Meskipun ada sedikit variasi dalam mendefinisikan apa yang merupakan "wholly obtained or produced" namun secara prinsip tetap sama. Produk yang tumbuh, dieksplorasi atau diperoleh dari suatu tempat, atau dalam hal produk manufaktur, jika diproduksi dari input yang berasal dari bahan lokal, produk ini diklasifikasikan sebagai "wholly obtained or produced" (Stefano Imana, 2009: 180). Secara umum, negara pemberi preferensial menyepakati daftar produk yang masuk kategori "wholly obtained or produced" di bawah ini (Stefano Imana, 2009: 180):

(a) mineral products extracted from its soil or from its seabed;

(b) vegetable products harvested there;

(c) live animals born and raised there;

(d) products obtained there from live animals;

(e) products obtained from hunting or fishing conducted there;

(f) products obtained from sea fishing and other products taken from the sea by its vessels;

(g) products made on board its factory ships exclusively from products referred to in $(f)$;

(h) used articles collected there fit only for the recovery of raw materials; 
(i) waste and scrap resulting from manufacturing operations conducted there; and

(j) products obtained there exclusively from products specified in (a) - (i).

Uni Eropa telah mengembangkan kriteria yang lebih ketat tentang persyaratan kapal yang digunakan untuk mencari dan mengolah produk-produk yang berasal dari laut (poin 6) (Stefano Imana, 2009: 180). Selain itu, terdapat perbedaan utama dalam menentukan asal-usul ikan yang ditangkap di Zona Ekonomi Ekslusif (ZEE). Dalam beberapa kasus, asal usul ikan dan barangbarang yang ditangkap/diambil dari ZEE ditetapkan berdasarkan pendaftaran kapal dan/atau bendera kapal, sementara pada kasus lain, asal barang ikan dan barang yang ditangkap/diambil dari wilayah ZEE dianggap berasal dari negara pantai (Ram Upendra Das and Rajan Sudesh Ratna, 2011: 28). Belum ada keseragaman mengenai masalah ini dan hal sama terjadi di WTO dan masih menjadi perdebatan di bawah The Harmonization Work Programme. Untuk ikan dan produk lainnya diambil dari laut territorial (tidak melebihi 12 mil), maka jelas asal barang ditetapkan berasal dari negara pantai tersebut.

Sementara untuk menentukan produk yang masuk klasifikasi "not wholly obtained or produced", digunakan tiga metode yaitu: (1) perubahan klasifikasi tariff (change of tariff classification); (2) penambahan nilai (value added); dan (3) proses produksi yang spesifik (specific manufacturing process).

Berdasarkan kriteria perubahan klasifikasi tarif (change of tariff classification), asal barang ditentukan jika produk akhir yang diekspor masuk dalam klasifikasi tarif yang berbeda dari klasifikasi tarif dari input impor (bahan baku, suku cadang, dan komponen) yang digunakan dalam proses produksi (Ram Upendra Das dan Rajan Sudesh Ratna, 2011: 85). Pelaksanaan metode ini ditentukan oleh Harmonized System (HS) (UNCTAD, 2011: 3).

Metode penambahan nilai (value added) adalah tingkat transformasi yang disyaratkan untuk memberikan status asal pada barang melalui prosentase minimum nilai input yang harus berasal dari negara pengekspor atau jumlah nilai maksimum yang berasal dari input impor yang digunakan (Edwin Vermulst, 1992: 62). Dengan kata lain, metode penambahan nilai ini dapat dinyatakan 
melalui dua cara: (1) dengan memberikan persentase minimum dari nilai produk (free on board/FOB) atau harga ex-pabrik (biaya yang harus ditambahkan di negara pengekspor (metode langsung perhitungan), atau (2) dengan memberikan persentase maksimum input non-asal untuk digunakan dalam pembuatan produk yang diekspor (metode penghitungan tidak langsung). Jika prosentase batas bawah tidak tercapai atau batas atas kelebihan, maka produk akhir tidak dapat diberi status asal. Jika tujuan penentuan asal barang utuk tujuan non-preferensial, maka status asal akan diberikan pada negara sebelumnya, dan jika untuk tujuan preferensial, maka tidak bisa ditentukan asal barang kecuali negara sebelumnya juga merupakan negara penerima preferensial berdasarkan perjanjian PTA (Joseph A. LaNasa III, 1996: 626).

Proses produksi yang spesifik (specific manufacturing process) diartikan bahwa pengolahan atau proses produksi tertentu atas suatu produk harus dilakukan di negara pengekspor untuk memberikan status asal (tes positif) atau tidak memberikan status asal (tes negatif) (Edwin Vermulst, 1992: 74). Dengan kata lain, status asal suatu produk dapat ditentukan dengan memperbolehkan penggunaan input dari negara pengekspor maupun melarang penggunaan input dari negara pengekspor. Aturan ini secara luas digunakan dalam hubungannya dengan perubahan klasifikasi tarif dan/atau kriteria nilai tambah, dan fitur tertentu dari aturan diterapkan pada sektor tekstil dan pakaian (Rajan Sudesh Ratna, 2007: 75).

\section{Pengaturan Rules of Origin di Indonesia}

Indonesia belum memiliki aturan yang lengkap dan komprehensif mengenai rules of origin. Rules of origin baru dimaknai sebatas aturan teknis tentang prosedur pemberian tatus asal dan belum menjadikan rules of origin sebagai sarana yang strategis bagi perdagangan internasional. Padahal, jika dikaji lebih lanjut, rules of origin memiliki peranan yang sangat penting di dalam lalu lintas perdagangan internasional. Salah satu peranan rules of origin adalah untuk mencegah terjadinya defleksi perdagangan (trade deflection). Defleksi perdagangan adalah masuknya produk yang berasal dari negara yang bukan anggota PTA melalui negara yang mempunyai tarif eksternal terendah, dengan 
tujuan untuk menghindari tariff tinggi (Chad P. Brown and Meredith A. Crowley, 176-201).

Secara umum, peraturan perundang-undangan Indonesia yang mengatur rules of origin baik secara langsung maupun tidak langsung adalah:

a. Undang-Undang Nomor 7 Tahun 1994 tentang Pengesahan Agreement Establishing the World Trade Organization.

b. Undang-Undang Nomor 7 Tahun 2014 tentang Perdagangan;

c. Undang-Undang Nomor 17 Tahun 2006 tentang Perubahan Atas UndangUndang Nomor 10 Tahun 1995 tentang Kepabeanan;

d. Peraturan Menteri Perdagangan RI Nomor 33/M-DAG/PER/8/2010 tentang Surat Keterangan Asal/SKA (Certificate of Origin). Untuk Barang Ekspor Indonesia, sebagai perubahan dari Peraturan Menteri Perdagangan RI Nomor 43/M-DAG/PER/10/2007 tentang Penerbitan Surat Keterangan Asal/SKA (Certificate Of Origin). Untuk Barang Ekspor Indonesia. Peraturan Menteri yang terakhir disebut ini mencabut Peraturan Menteri Perdagangan Nomor 17/M-DAG/PER/9/2005 tentang Penerbitan Surat Keterangan Asal (Certificate of Origin) untuk Barang Ekspor Indonesia;

e. Peraturan Menteri Perdagangan RI Nomor 59/M-DAG/PER/12/2010 tentang Ketentuan Penerbitan Surat keterangan Asal (Certificate of Origin) Untuk Barang Ekspor Indonesia.

f. Peraturan Menteri Perdagangan RI Nomor 60/M-DAG/PER/12/2010 tanggal 30 Desember 2010 tentang Instansi Penerbit Surat Keterangan Asal (Certificate Of Origin) Untuk Barang Ekspor Indonesia.

g. Surat Edaran Direktur Jenderal Bea dan Cukai Nomor 5/BC/2010 tentang Petunjuk Pelaksanaan Penelitian Dokumen Pemberitahuan Impor Barang dalam Rangka Skema Free Trade Agreement,

h. Operational Certificate Procedures (OCP) atau Prosedur Sertifikasi Operasional yang merupakan penerbitan SKA berdasarkan perjanjian Free Trade Agreement (FTA) dimana Indonesia sebagai salah satu pihak penendatanganannya OCP tersebut diantaranya ASEAN-India FTA, AJCEP, dan AJCEP, dan AANZ FTA. 


\section{Permasalahan Hukum yang Timbul terkait Pengaturan Rules of Origin di Indonesia}

Konsekuensi ratifikasi Indonesia terhadap perjanjian pendirian the World Trade Organization (WTO) melalui Undang-Undang Nomor 7 Tahun 1994 adalah bahwa pemerintah Indonesia dikenai kewajiban hukum dalam hukum internasional (Natalie Baird, 2011: 4) Pasal 26 Konvensi Wina menyatakan bahwa negara tidak dapat menghindar dari kewajiban internasional yang lahir dari proses mengikatan diri terhadap perjanjian internasional tanpa alasan yang jelas. Oleh sebab itu, Indonesia harus melaksanakan semua isi perjanjian WTO baik melalui peraturan perundang-undangan nasional maupun melalui kebijakan nasional (Boer Mauna, 2005: 145). Terlebih, pendekatan yang digunakan oleh WTO adalah pendekatan "single undertaking" dimana setiap negosiasi WTO merupakan bagian yang tak terpisahkan dari semua paket negosiasi yang ada dan tidak dapat disetujui secara terpisah (nothing is agreed until everything is agreed) (Robert Wolfe, 2009: 834-835). Hal ini berarti pula bahwa Indonesia harus mengatur dan melaksanakan semua aturan WTO hasil negosiasi tanpa kecuali termasuk aturan mengenai rules of origin yang terdapat dalam Annex 1A Agreement Establishing of World Trade Organization (Agreement on Rules of Origin).

Undang-Undang Nomor 7 Tahun 2014 tentang Perdagangan tidak mengatur masalah rules of origin secara langsung. Aturan yang secara tidak langsung mengatur rules of origin terdapat dalam Bab XII Pasal 87 (1) yang menyatakan: “..Pemerintah dapat memberikan preferensi perdagangan secara unilateral kepada negara kurang berkembang dengan tetap mengutamakan kepentingan nasional."

Walaupun pada bagian penjelasan dikatakan bahwa pasal ini "cukup jelas", namun sebenarnya pasal ini mengandung beberapa hal penting. Pertama, dalam hal ini, Indonesia dapat berlaku sebagai "negara pemberi" preferensial (giving country). Pertanyaan mendasar yang berkaitan dengan kondisi ini adalah sebagai negara pemberi, kriteria barang atau jasa seperti apa yang akan diberi fasilitas preferensial. Berkaitan dengan hal ini, maka rules of origin merupakan 
mekanisme yang paling tepat untuk menjawab pertanyaan mendasar tersebut. Kedua, istilah "unilateral" di sini dapat berarti bahwa pemberian preferensial bersifat sepihak atau non-reciprocity. Artinya, pemberian preferensial oleh suatu negara tidak harus dibayar dengan suatu konsesi yang bersifat timbal balik (Stephanie Switzer, 2008: 114-115). Praktek serupa juga dilakukan oleh negaranegara maju kepada negara berkembang dan miskin dalam hal pemberian fasilitas Generalized System of Preference/GSP (Gregory Shaffer and Yuonne Apea, 2005: 977-1008), misalnya praktek pemberian GSP oleh Uni Eropa, Jepang dan Amerika Serikat. Selanjutnya, prinsip "unilateral” ini juga menyimpangi prinsip "most-favoured-nation" yang telah menjadi pilar dalam perdagangan internasional (Tony Cole, 2012: 545). Ketiga, istilah "negara kurang berkembang” yang dalam hal ini dianggap sebagai "negara penerima" preferensial (receiving country). Kriteria apa agar suatu negara dapat disebut sebagai "negara kurang berkembang” sehingga bisa mendapatkan fasilitas preferensial? Berdasarkan uraian ini, maka dapat penulis katakan bahwa Pasal 87 (1) Undang-Undang Nomor 7 Tahun 2014 tentang Perdagangan secara tidak langsung merupakan dasar bagi pengaturan rules of origin lebih lanjut di Indonesia.

Undang-Undang Nomor 10 Tahun 1995 entang Kepabeanan yang diubah menjadi Undang-Undang Nomor 17 Tahun 2006 tidak pula mengatur rules of origin secara khusus. Namun demikian, Pasal 25 dan 26 mengatur mengenai Pembebasan dan Keringanan Bea Masuk. Kedua pasal tersebut menyebutkan daftar barang-barang impor yang dapat dikenai pembebasan dan/atau keringanan bea masuk. Dari sini terlihat bahwa Indonesia belum mengatur secara khusus rules of origin sebagai dasar suatu barang dan jasa dapat menikmati fasilitas preferensial. Bahkan jika dicermati lebih teliti, daftar barang-barang impor yang bisa mendapatkan pembebasan atau keringanan bea masuk yang terdapat pada Pasal 26, ada beberapa barang yang masuk kriteria "wholly obtained" dan "not wholly obtained" sesuai dengan kriteria barang berdasarkan ketentuan rules of origin.

Pasal 26 (1) huruf f menyatakan bahwa barang yang dapat diberikan pembebasan atau keringanan atasnya adalah hasil laut yang telah ditangkap 
dengan sarana penangkap yang telah mendapatkan izin. Berdasarkan Agreement on Rules of Origin (AROO) WTO maupun ASEAN Trade in Good Agreement (ATIGA), semua hasil laut merupakan produk yang masuk kategori "wholly obtained" dalam ketentuan rules of origin. Begitu pula pada Pasal 26 (1) huruf k yang menyatakan bahwa barang yang dapat diberi pembebasan atau keringanan tarif adalah barang dan bahan untuk diolah, dirakit, atau dipasang pada barang lain dengan tujuan untuk diekspor. Berdasarkan ketentuan rules of origin, baik yang terdapat dalam AROO WTO maupun ATIGA, barang yang diimpor dengan tujuan untuk diberi nilai tambah (diolah, dirakit, atau dipasang pada barang lain) dan kemudian diekspor kembali masuk dalam kriteria "not wholly obtained".

Berdasarkan dua undang-undang di atas, yaitu Undang-Undang Nomor 7 Tahun 2014 tentang Perdagangan dan Undang-Undang Nomor 10 Tahun 1995 tentang Kepabeanan yang diubah menjadi Undang-Undang Nomor 17 Tahun 2006 dapat dikatakan bahwa Indonesia belum mengatur ketentuan rules of origin secara jelas.

Aturan teknis yang berada di bawah undang-undang yang secara langsung mengatur rules of origin adalah Peraturan Menteri Perdagangan Nomor 33/M-DAG/PER/8/2010 tentang Surat Keterangan Asal/ SKA (Certificate of Origin) untuk Barang Ekspor Indonesia; Peraturan Menteri Perdagangan Nomor 59/M-DAG/PER/12/2010 tentang Ketentuan Penerbitan Surat Keterangan Asal (Certificate of Origin) untuk Barang Ekspor Indonesia; dan Surat Edaran Direktur Jenderal Bea dan Cukai Nomor 1/BC/2010 tentang Petunjuk Pelaksanaan Penelitian Surat Keterangan Asal Atas Barang Impor Dalam Skema Free Trade Agreement.

Peraturan Menteri Perdagangan RI Nomor 33/M-DAG/PER/8/2010 tentang Surat Keterangan Asal (Certificate of Origin). Untuk Barang Ekspor Indonesia merupakan perubahan dari Peraturan Menteri Perdagangan RI Nomor 43/M-DAG/PER/10/2007 tentang Penerbitan Surat Keterangan Asal (Certificate Of Origin) Untuk Barang Ekspor Indonesia. Peraturan Menteri Perdagangan yang disebut terakhir ini mencabut Peraturan Menteri Perdagangan Nomor 17/MDAG/PER/9/2005 tentang Penerbitan Surat Keterangan Asal (Certificate of 
Origin) untuk Barang Ekspor Indonesia. Peraturan ini mengatur mengenai surat keterangan asal bagi barang yang diekspor oleh Indonesia. Disini berarti Indonesia bertindak sebagai pihak "negara penerima" fasilitas preferensial. Artinya, Indonesia adalah negara yang mengajukan permohonan fasilitas preferensial kepada negara maju. Oleh sebab itu, kualifikasi barang yang mendapat fasilitas preferensial sepenuhnya ditetapkan oleh "negara pemberi" preferensial. Indonesia sebagai pihak pemohon harus memenuhi syarat-syarat ketentuan rules of origin yang ditetapkan oleh negara pemberi preferensial jika ingin mendapatkan fasilitas tersebut. Hal ini adalah implikasi dari prinsip unilateral yang menjadi dasar dalam pemberian fasilitas preferensial.

Berdasarkan Pasal 1 angka 1 Peraturan Menteri Perdagangan Nomor 33/M-DAG/PER/8/2010, yang dimaksud ketentuan asal barang (rules of origin) adalah "peraturan perundang-undangan dan ketentuan administratif dari penerapan secara umum yang diterapkan oleh suatu negara anggota WTO untuk menentukan negara asal barang." Definisi mengenai rules of origin dalam peraturan ini tidak jelas. Bagaimana cara menentukan asal barang tidak dijelaskan lebih lanjut. Apa tujuan rules of origin bagi Indonesia juga tidak dijelaskan. Kalimat “...yang diterapkan oleh suatu negara anggota WTO” dapat diartikan bahwa cara dan metode untuk menentukan bahwa suatu barang berasal dari Indonesia ditentukan oleh negara anggota WTO yang akan memberi fasilitas preferensial kepada Indonesia.

Ketentuan rules of origin dalam Peraturan Menteri Nomor 33/MDAG/PER/8/2010 ini baru dimaknai sebatas "ketentuan administratif" mengenai asal barang. Peraturan Menteri ini lebih banyak mengatur tentang tata cara penerbitan Surat Keterangan Asal (SKA). Pengertian Surat Keterangan Asal (certificate of origin) menurut Pasal 1 angka 1 Peraturan Menteri Perdagangan ini adalah dokumen yang disertakan pada waktu barang ekspor Indonesia yang telah memenuhi ketentuan asal barang (rules of origin) memasuki wilayah negara tertentu yang membuktikan bahwa barang tersebut berasal dari Indonesia. Surat keterangan asal terdiri dari dua jenis yaitu SKA preferensi dan SKA nonpreferensi. SKA preferensi diterbitkan untuk memperoleh fasilitas pengurangan 
atau pembebasan tarif bea masuk yang diberikan oleh suatu negara atau sekelompok negara terhadap barang ekspor Indonesia yang memenuhi syarat sesuai ketentuan perjanjian internasional atau penetapan unilateral. Sedangkan SKA non-preferensi diterbitkan untuk memenuhi ketentuan yang ditetapkan oleh suatu negara atau sekelompok negara terhadap barang ekspor Indonesia berdasarkan perjanjian internasional atau penetapan unilateral. Surat keterangan asal diterbitkan oleh instansi/badan/lembaga yang ditetapkan sebagai instansi penerbit SKA oleh direktur jenderal untuk dan atas nama menteri.

Lebih lanjut, berdasarkan Peraturan Menteri Perdagangan Nomor 60/MDAG/PER/12/2012 tentang Instansi Penerbit Surat Keterangan Asal (Certificate of Origin) untuk Barang Ekspor Indonesia, terdapat 85 instansi penerbit surat keterangan asal yang tersebar di 34 propinsi di Indonesia. Selanjutnya, ada instansi penerbit surat keterangan asal untuk barang ekspor tertentu yang berasal dari Indonesia, yaitu:

a. Untuk tekstil dan produk tekstil untuk tujuan ekspor ke Amerika Serikat dan Uni Eropa ada 30 instansi;

b. Untuk produk alas kaki ada 28 instansi;

c. Untuk udang ada 18 instansi; dan

d. Untuk kopi ada 13 instansi.

Berkaitan dengan banyaknya instansi di tiap daerah yang diizinkan menerbitkan surat keterangan asal, terdapat kasus di Kabupaten Sumbawa Barat terkait terbitnya Peraturan Bupati Kabupaten Sumbawa Barat Nomor 30 Tahun 2010 tentang Surat Keterangan Asal Barang (SKAB). Peraturan Bupati ini menyatakan bahwa Bupati Sumbawa Barat berhak menerbitkan Surat Keterangan Asal Barang terkait dengan barang tambang (dalam hal ini adalah konsentrat tembaga). Peraturan Bupati Sumbawa Barat Nomor 30 Tahun 2010 tanggal 29 September 2010 ini bersifat overlapping karena bertentangan dengan Peraturan Menteri Perdagangan Nomor 60/M-DAG/PER/12/2012 tentang Instansi Penerbit Surat Keterangan Asal (Certificate of Origin) untuk Barang Ekspor Indonesia serta Keputusan Presiden Nomor 58 Tahun 1971 tentang Penetapan Pejabat yang Berwenang Mengeluarkan Surat Keterangan Asal, dimana menteri perdagangan 
mempunyai kewenangan dalam penerbitan surat keterangan asal, bukan bupati selaku kepala daerah. Selain itu, dasar pertimbangan Peraturan Bupati ini adalah Peraturan Menteri Perdagangan Nomor 43 tahun 2007 tentang Surat Keterangan Asal (Certificate of Origin) untuk Barang Ekspor Indonesia, yang pada waktu diterbitkan Peraturan Bupati, Peraturan Menteri ini telah dicabut dan diganti dengan Peraturan Menteri Perdagangan Nomor 33/M-DAG/PER/8/2010.

Kasus di atas memberi pelajaran bagi Indonesia bahwa penerbitan surat keterangan asal bagi barang ekspor Indonesia seharusnya ditangani oleh suatu badan tunggal yang terkoordinasi dengan tiap propinsi di Indonesia. Masalah kelembagaan dari rules of origin di Indonesia menjadi persoalan yang harus segera diselesaikan. Belum adanya lembaga (unit) yang secara khusus menangani implementasi skema PTA di Indonesia menimbulkan ketidakjelasan lembaga mana sebenarnya yang harus bertanggung jawab atas rules of origin, baik pada saat negosiasi, implementasi, monitoring, sampai dengan evaluasi. Kondisi ini menimbulkan kesulitan dalam komunikasi dan koordinasi antara petugas di lapangan dengan lembaga yang ada di kantor pusat. Sementara di kantor pusat sendiri belum terdapat unit yang secara khusus diberikan tugas untuk permasalahan PTA. Hal ini berbeda dengan negara-negara lain dan kawasan lain yang telah memiliki unit rules of origin di dalam struktur organisasinya. Korean Customs Services misalnya, adalah unit di bawah kepabeanan Korea Selatan yang menangani masalah PTA sejak negosiasi hingga implementasi. Jepang yang memiliki unit Customs and Tariff Bureau, di bawah Kementerian Keuangan Jepang, yang juga bertanggung jawab atas pengaturan dan pelaksaan PTA termasuk rules of origin. Bahkan beberapa kepabeanan di negara ASEAN juga telah memiliki unit ini, seperti Compliance and Trade Facilitation, Singapore Customs; Royal Malaysian Customs Department (Jabatan Kastam Diraja Malaysia); Vietnam Customs, The Customs Department of Thailand, dan sebagainya. Pengaturan rules of origin di Uni Eropa ditangani oleh Taxation and Customs Union.

Berdasarkan Pasal 7 (2) Peraturan Menteri Perdagangan Nomor 33/MDAG/PER/8/2010, surat keterangan asal dapat diperoleh eksportir dengan 
mengajukan permohonan kepada instansi penerbit surat keterangan asal dengan dilengkapi dokumen pendukung berupa:

a. Fotokopi Pemberitahuan Ekspor Barang (PEB) yang telah difiat-muat oleh petugas Kantor Pelayanan Bea dan Cukai di pelabuhan muat atau lembar cetak (print out) PEB yang dibuat secara Pertukaran Data Elektronik (PDE) dengan dilampiri Nota Persetujuan Ekspor (NPE);

b. Tindasan asli (original copy) Bill of Lading (B/L) atau fotokopi Air Way Bill (AWB), atau fotokopi Cargo Receipt jika pelaksanaan ekspornya melalui pelabuhan darat;

c. Fotokopi Nomor Pokok Wajib Pajak (NPWP);

d. Invoice;

e. Packing list; dan

f. Dokumen lain sesuai dengan jenis SKA berdasarkan peruntukannya.

Terhadap setiap permohonan penerbitan SKA, instansi penerbit SKA harus meneliti dan memeriksa:

a. Pemenuhan ketentuan asal barang (rules of origin) sesuai dengan ketentuan perjanjian internasional atau penetapan unilateral;

b. Kebenaran informasi yang disampaikan eksportir; dan

c. Kelengkapan dokumen pendukung.

Dalam rangka operasionalisasi ketentuan mengenai tata cara penerbitan surat keterangan asal, Pemerintah Indonesia mengeluarkan Peraturan Menteri Perdagangan Nomor 59/M-DAG/PER/12/2010 tentang Ketentuan Penerbitan Surat Keterangan Asal untuk Barang Ekspor Indonesia. Karena Peraturan Menteri Perdagangan ini berkaitan dengan barang ekspor Indonesia, maka dalam menentukan asal barang, Indonesia hanya memenuhi persyaratan yang telah ditetapkan oleh negara pemberi fasilitas preferensial atau persyaratan yang telah tetapkan dalam perjanjian kerjasama perdagangan bebas, baik yang bersifat bilateral, regional maupun multilateral. Indonesia belum memiliki aturan yang jelas dan rinci dalam rangka menjabarkan aturan-aturan yang telah disepakati tadi. Misalnya, bagaimana aturan Indonesia terhadap produk ekspornya agar memenuhi ASEAN Regional Value Content (kandungan lokal ASEAN) sebesar 40\%. Hal ini 
tentu saja akan menyulitkan baik bagi eksportir Indonesia maupun bagi petugas di lapangan.

Sebagaimana telah dijelaskan sebelumnya, bahwa Pasal 87 (1) UndangUndang Nomor 7 Tahun 2014 tentang Perdagangan merupakan dasar hukum bagi Indonesia untuk menyusun aturan mengenai rules of origin. Pasal ini menyatakan bahwa Pemerintah Indonesia dapat memberikan preferensi perdagangan secara unilateral kepada negara kurang berkembang dengan tetap mengutamakan kepentingan nasional. Artinya, selain produk ekspor dari Indonesia yang memerlukan aturan khusus mengenai rules of origin, produk impor yang masuk ke Indonesiapun harus memenuhi kualifikasi tertentu yang ditetapkan Indonesia, sebagai negara pemberi preferensial, untuk bisa mendapatkan fasilitas preferensial, termasuk pengurangan tarif. Namun demikian, Indonesia juga belum memiliki aturan mengenai rules of origin bagi produk impor.

Kekosongan aturan mengenai rules of origin, baik untuk produk ekspor maupun produk impor, dapat menimbulkan ketidakadilan dalam praktek perdagangan internasional. Hal ini karena suatu negara yang bukan anggota PTA suatu kawasan dapat memasukkan produknya melalui negara anggota PTA yang memiliki tarif eksternal paling rendah, untuk kemudian produk tersebut diekspor kembali ke negara yang memiliki tarif eksternal yang lebih tinggi dalam kawasan tersebut (Moshe Hirsch, 2002: 171). Dengan demikian, negara yang bukan anggota PTA tersebut dapat menghindari tarif tinggi yang dikenakan atas produknya untuk dipasarkan ke kawasan tersebut. Dalam hal ini, rules of origin berperan untuk mencegah terjadinya defleksi perdagangan, mengingat tiap negara anggota FTA biasanya memiliki tarif eksternal yang berbeda-beda.

Rules of origin tidak hanya berpotensi sebagai instrumen kebijakan perdagangan, namun juga pada kenyataannya berdampak pada aliran perdagangan internasional (Vermulst and Waer, 1990: 55-121). Sebuah kawasan perdagangan bebas di bawah perjanjian preferensial yang memiliki ketentuan rules of origin kumulatif biasanya lebih liberal dibandingkan dengan kawasan yang tidak memiliki ketentuan rules of origin kumulatif. Hal ini karena berdasarkan ketentuan rules of origin kumulatif, bahan produksi dan barang yang berasal dari 
satu negara anggota kawasan regional dianggap berasal dari negara di mana pengolahan terakhir dilakukan dan bukan dianggap sebagai barang impor. Dengan kata lain, bahan produksi yang berasal dari dalam suatu negara anggota kawasan regional dibebaskan dari norma-norma penambahan nilai karena tidak dianggap sebagai impor ke negara di mana proses produksi berlangsung. Hal ini berpotensi meningkatkan arus perdagangan intra-regional dari berbagai kategori barang (barang jadi, barang setengan jadi dan barang intermediet) dan juga sekaligus dapat meningkatkan arus investasi dan transfer teknologi serta memiliki efek neraca perdagangan yang menguntungkan bagi negara yang menerapkan rules of origin kumulatif.

\section{Simpulan}

Ada beberapa permasalahan hukum yang timbul dalam kaitan dengan pengaturan rules of origin di Indonesia. Pertama, Indonesia belum memiliki aturan rules of origin yang bersifat komprehensif. Akibatnya, Indonesia berpotensi untuk dirugikan dalam lalu lintas perdagangan internasional. Kedua, masalah kelembagaan perihal siapa yang bertanggung jawab atas perumusan aturan rules of origin dan implementasinya. Indonesia belum memiliki lembaga yang khusus menangani PTA, sehingga hal ini menyulitkan banyak pihak, tidak saja pihak pelaku perdagangan internasional, tapi juga pihak pemerintah. Kesulitan dalam komunikasi dan koordinasi antara petugas di lapangan dengan lembaga yang ada di kantor pusat. Sementara di kantor pusat sendiri belum ada unit yang secara khusus diberikan tugas untuk permasalahan PTA. Ketiga, aturan mengenai rules of origin di Indonesia masih dimaknai sebatas aturan teknis saja. Padahal sesungguhnya rules of origin memiliki peran yang penting dan strategis dalam sistem perdagangan internasional.

\section{E. Saran}

Beberapa hal yang disarankan dalam penelitian ini adalah:

1. Kepada Pemerintah Indonesia untuk segera mengatur rules of origin dalam Undang-Undang. 
2. Kepada Pemerintah Indonesia segera membuat lembaga yang khusus menangani preferential trade agreement, yang di dalamnya termasuk menangani masalah rules of origin. 


\section{DAFTAR PUSTAKA}

A. LaNasa III, Joseph. 1996. "Rules of Origin and the Uruguay Round's Effectiveness in Harmonizing and Regulating Them". American Journal of International Law, Vol. 90.

Baird, Natalie. 2011. "To Ratify or not to Ratify? An Assessment of Case for Ratification of International Human Rights Treaties in the Pacific". Melbourne Journal of International Law, Vol. 12.

Bhagwati, Jagdish. 2008. Termites in the Trading System: How Preferential Agreements Undermine Free Trade. New York: Oxford University Press.

Boer Mauna. 2005. Hukum Internasional: Pengertian, Peranan dan Fungsi Dalam Era Dinamika Global, Edisi Kedua. Bandung: Alumni.

Bum Kim, Jong and Joongi Kim. 2009. "RTAs for Development: Utilizing Territoriality Principle Exemptions under Preferential Rules of Origin", Journal of World Trade Vol.43 No. 1.

Cole, Tony. 2012. "The Boundaries of Most Favoured Nation Treatment in International Investment Law". Michigan Journal of International Law, Vol. 33 Issue 3.

Hirsch, Moshe. 2002. "Rules of Origin as Trade or Foreign Policy Instruments? The European Union Policy on Products Manufactured in the Settlements in the West Bank and the Gaza Strip". Fordham International Law Journal, Vol. 26, Issue 3.

Hirsch, Moshe. 2002. "International Trade Law, Political Economy and Rules of Origin: A Plea for a Reform of the WTO Regime on Rules of Origin”. Journal of World Trade, Vol. 36(2).

H. J. Bourgeois, Jacques. 1994. "Rules of Origin: An Introduction", dalam Edwin Vermulst, et al (Eds), Rules of Origin in International Trade: A Comparative Study. Michigan: University of Michigan Press.

H. Malkawi, Bashar. 2011. "Rules of Origin under U.S. Trade Agreements with Arab Countries: Are they Helping and Hindering Free Trade?". Journal of International Trade Law and Policy, Vol. 10 ISS. 1.

Jakob, Thinam and Gernot Fiebiger. 2003. "Preferential Rules of Origin-A Conceptual Outline", Intereconomics, Vol. May/June.

J. Barcelo III, John. 2006. Harmonizing Preferential Rules of Origin in the WTO System. Legal Studies Research Paper Series. New York: Cornel Law Faculty Publication.

J. Llyod, P. 1993. "A Tariff Substitute for Rules of Origin in Free Trade Area". The World Economy, Volume 16, Issue 6.

Krishna, Kala. 2005. Understanding Rules of Origin. NBER Working Paper No. 11150. Cambridge: National Bureau of Economic Research.

P. Brown, Chad and Meredith A. Crowley. 2007. "Trade Deflection and Trade Depression". Journal of International Economic, Vol. 72(1).

Shaffer, Gregory and Yuonne Apea. 2005. "Institutional Choice in the Generalized System of Preference Case: Who Decides the Condition for Trade Preference? The Law and Politics of Rights". Journal of World Trade, Vol. 39(5). 
Soerjono Soekanto dan Sri Mamudji. 2007. Penelitian Hukum Normatif Suatu Tinjauan Singkat. Jakarta: Rajawali Pers.

Stefano Inama. 2009. Rules of Origin in Internatioal Trade. Cambridge: Cambridge University Press.

Sudesh Ratna, Rajan. 2011. Rules of Origin: Developing Country's Perspective. Tanpa kota: GSTP Project, UNCTAD.

Switzer, Stephanie. 2008. "Environment Protection and The Generalized System of Preferences: A Legal and Appropriate Linkage?", ICLQ, Vol. 57.

UNCTAD. 2011. Rules of Origin and Origin Procedures Applicable to Exports from Least Developed Countries. Geneva: United Nations Publication.

UNESCAP. 2007. Towards Coherent Policy Frameworks: Understanding Trade and Investment Linkages. Bangkok: United Nations Publication.

Upendra Das, Ram and Rajan Sudesh Ratna. 2011. Perspectives on Rules of Origin: Analytical and Policy Insights from the Indian Experience. United Kingdom: PalgraveMacmillan.

Vermulst, Edwin. 1992. "Rules of Origin as Commercial Policy Instruments Revisited". Journal of World Trade, Vol. 26(6).

Vermulst, Edwin and Waer. 1990. "European Community Rules of Origin as Commercial Policy Instruments?", Journal of World Trade, Vol. 43(3).

Wolfe, Robert. 2009. "The WTO Single Undertaking as Negotiating Technique and Constitute Metaphor". J. Int Economic Law, Vol. 12(4).

\section{Konvensi Internasional dan Peraturan Perundang-undangan:}

Agreement on Rules of Origin

Undang-Undang Nomor 7 Tahun 1994 tentang Pengesahan Agreement Establishing the World Trade Organization.

Undang-Undang Nomor 7 Tahun 2014 tentang Perdagangan.

Undang-Undang Nomor 17 Tahun 2006 tentang Perubahan Atas Undang-Undang Nomor 10 Tahun 1995 tentang Kepabeanan.

Peraturan Menteri Perdagangan RI Nomor 33/M-DAG/PER/8/2010 tentang Surat Keterangan Asal/SKA (Certificate of Origin).

Peraturan Menteri Perdagangan RI Nomor 43/M-DAG/PER/10/2007 tentang Penerbitan Surat Keterangan Asal/SKA (Certificate of Origin).

Peraturan Menteri Perdagangan Nomor 17/M-DAG/PER/9/2005 tentang Penerbitan Surat Keterangan Asal (Certificate of Origin) untuk Barang Ekspor Indonesia.

Peraturan Menteri Perdagangan RI Nomor 59/M-DAG/PER/12/2010 tentang Ketentuan Penerbitan Surat keterangan Asal (Certificate of Origin) Untuk Barang Ekspor Indonesia.

Peraturan Menteri Perdagangan RI Nomor 60/M-DAG/PER/12/2010 tanggal 30 Desember 2010 tentang Instansi Penerbit Surat Keterangan Asal (Certificate Of Origin) Untuk Barang Ekspor Indonesia.

Surat Edaran Direktur Jenderal Bea dan Cukai Nomor 5/BC/2010 tentang Petunjuk Pelaksanaan Penelitian Dokumen Pemberitahuan Impor Barang dalam Rangka Skema Free Trade Agreement. 